\title{
Impact of Stock Market Development on Economic Growth in BRICS
}

\author{
Godfrey Osaseri ${ }^{1} \&$ Ifuero Osad Osamwonyi ${ }^{2}$ \\ ${ }^{1}$ Department of Economics, School of Art and Social Sciences, College of Education, Benin City, Edo State, Nigeria \\ ${ }^{2}$ Department of Banking \& Finance, University of Benin, Nigeria \\ Correspondence: Ifuero Osad Osamwonyi, Ph.D., Department of Banking \& Finance, University of Benin, Nigeria.
}

Received: November 26, 2018

Accepted: December 28, 2018

Online Published: January 6, 2019

doi:10.5430/ijfr.v10n1p23

URL: https://doi.org/10.5430/ijfr.v10n1p23

\begin{abstract}
The study examines Stock Market development and economic growth in BRICS, Quarterly time series data for the period 1994QI to 2015Q4 were sourced from World Bank Indicator. The Panel Least Squares based on the fixed effect estimation was employed to determine how stock market development impacts on the economic growth of BRICS. Diagnostics tests were conducted to ascertain the robustness and stability of the regression results. The findings reveal that stock market development exerts significant impact on the economic growth. The study revealed that there is a positive correlation between stock market development indicators and BRICS's economic growth. The study recommends that the weakness of each of the BRICS member country should be taken as policy focus and strategies necessary to strengthen them should be swiftly applied by the governments.
\end{abstract}

Keywords: stock market, real gross domestic product, market capitalization, inflation rate

JEL Classification: G10, E44

\section{Introduction}

Brazil, Russia, India, China and South Africa make up the BRICS as described in O'Neil (2001). Global Sherpa (2009) emphasizes that BRICS block is to grow the cooperation that addresses the challenges of emerging economies. The Goldman Sachs team project report in 2005 placed the BRICS countries consistently in the top half of the global rankings, among the best environments for sustained economic growth. The BRICS concept since it began to emerge as a physical reality has been focused on economic growth projection without any relevance to other parameters such as political/social development inclusivity, let alone sustainability. It therefore follows that the only uniting factor is the scale of their economies in terms of gross domestic product (GDP) and their sustained growth rates.

However, one of the difficulties of examining cross-section studies on BRICS countries have always been the fact that each of the countries have varying stock market strength, corporate governance structure, political climate, investment climate and much more economic conditions. It has been predicted by O'Neil (2001) that BRICS countries may overtake the G-7 countries in the nearest future given the relationship between their stock markets and the growth of the economies. However, the size and performance of the stock market in the individual BRICS country do differ significantly. The stock market in Brazil is growing but it is not well developed; it has low capitalization, few initial offerings, low liquidity, and transactions are concentrated in few shares (Moura, 2005). Matos (2003) used the Granger Causality Test to establish bidirectional relationship between stock market development and economic growth in Brazil. Andrezo and Lima (2012) argue that there is disagreement over the direction of causality between the development of stock market and economic growth in Russia. Kamaiah and Biswal (2000) found positive association in India. This was confirmed by Biswal and Veerashekharappa (2002); they identified a significant relationship between the stock market development and economic growth process in India. Agrawala and Tuteja (2007) confirmed a stable long run equilibrium relationship.

Ruyong (1990) using the period 1994 - 1998 found that in China stock market development does not impact economic growth. Wang (2002) using China's stock market quarterly data disclosed that market liquidity has limited effect on economic growth. Mu Qing, Robert and Chang (2001) report that stock market capitalization, turnover and trading volume have not significantly impacted on the growth of China's economy. Similarly, Zhao (2002) identifies only a weak negative correlation. With Vector Error Correction Model (VECM), Ndako (2008) examined the casual relationship between stock markets, banks and economic growth in South. The empirical investigation suggests that in the long-run, there is evidence of bidirectional causality between stock market development and economic growth. 
It may be concluded from the review so far that studies that empirically focus on how stock market development engenders the economic growth of Brazil, Russia, India, China and South Africa (BRICS) in a unified or aggregate manner are few and conflicting if they exist at all.

\section{Literature Review}

By the 1970s, Brazil became the leading economy in Latin America due to its industrialization, natural resources and large labour pool. Brazil is the eight largest economy in the world (Clemente, Taffarel \& Espejo, 2013). A long period of high inflation rate and general economic instability impacted negatively on the Brazilian stock market until mid - 1990s (Clemente et al. 2013). The Brazilian stock market initiated various reforms since 2003, and this was followed by an intense inflow of foreign capital. These have grown the stock market (Bovespa) to the fifth Bourse in the world in terms of foreign investors' participation (Clemente et al, 2013)

Many studies have examined the nexus between stock market development and economic growth in Russia. El Wassai (2005) investigated the impact of stock market development using indicators such as market capitalization, turnover ratio and value of shares traded on the economic growth for Russia. The result shows that market capitalization did not significantly influence the economic growth of Russia. While turnover ratio and value of shares showed positive relationship but they were not statistically significant. Garcia and Liu (1999) in their study of the economy of Russia, reveal that stock market development positively enhance economic growth. Olfa (2007) while examining the impact of certain stock market development on the growth of the Russian economy found significant positive relationship. The conclusion drawn was the need to strengthen the legal environment favourable to inflow of foreign direct investment. Dailami and Aktin (1990) concluded that a developed stock market can enhance savings and provide investment capital at lower cost in its financial intermediation.

The causal nexus between stock market development and economic growth was examined by Vazakidis and Adawopoulos (2009) in Russia. The study indicates that there is a positive association between economic growth and stock market development, while interest rate has a negative effect on stock market development. Brasoveanu (2008) examined the relationship between capital market development and economic growth in Russia, and identified a positive correlation. The strongest link however, is from economic growth to capital market. India has adopted modern strategies to promote its stock market growth since late 1970s, but by 1991, the reforms have become more sophisticated (Sudharshan \& Rakesh, 2011). As noted by Nagashi (1999), the result is that India is transforming into one of the most active market among developing countries. Sinha and Macrie (2001) indentified a positive and statistically significant relationship between income and financial variables for India. The result of Kamat and Kamat (2007) supports that stock market development stimulate economic growth in the short-run. Acharya, Amanulla and Joy (2009) examined the nexus between stock market development and economic growth in Indian, and conclude that there is long-run relationship between stock market development and growth across India state. Padban (2007) examined the causal linkages between stock market development and economic activity in India for the post liberalization period. The result was a bidirectional relationship between stock prices and economic activity. Agrawalla and Tuteja (2007) also found that stable long- run equilibrium relationship exists between stock market development and economic growth in India. Deb and Mukherjee (2008) also found for India a strong causal flow from the stock market development to economic growth and also stressed that there is a bi-directional relationship between market capitalization and economic growth.

During the early period of the privatization programme in China, attempts were made to use capital market pressures to improve the performance of state - owned enterprises (Ahn \& Cogman, 2007). To allow companies to raise capital, a two - tier ownership structure was put in place and until 2001 domestic investors could only buy "A shares" while foreign investors could hold "B shares" (Wang \& Ajit, 2013). Wang and Ajit (2013) noted that despite the capital market segmentation, the stock market has developed quickly. Wang (2002) in his study concludes that there is no obvious correlation between China's capital market development and economic growth. Researchers such as Wang and Li (2004); Burdekin and Redferm (2009) have identified segmentation of the equity market, illiquidity, herding behaviour and inefficiency as the reasons for its limited impact on the China's economy. Duan (2012) in his study did not obtain any evidence of causality. Ruyong (1999) indicated that during the period 1994-1998, China's stock market development had only a little impact on economic growth. Wang (2001) demonstrated that China's stock market liquidity has limited effect on economic growth. The result of Zheng, Yuan and Hu (2000) was not different. MuQing, Robert, \& Chang, (2001) found that the stock market transactions increased with the number of fixed assets of state-owned units. Based on the data of 1994-2001 and quarterly economic growth, Zhao (2002) found that there is a positive relationship between trading value and economic growth. 
Chipaumire and Ngirande (2014) examined how stock market liquidity impact economic growth in South Africa. They conclude that stock market liquidity impact growth in South Africa. Ndako (2008) result showed that stock market development impact significantly on economic growth of South Africa. This robust positive finding may intuitively be linked to the developing nature, size and reform of the South Africa financial system. More recent studies affirming the relationship include Masoud (2013), Bayar, Kaya and Yildirım (2014), Brown and Nyeche (2016), Pan and Mishra (2018), and Najeb and Masoud (2013). Supporting evidence from Nigeria can be found in Osamwonyi and Kasimu (2013), and Ikikii and Nzomoi (2013).

\section{Methodology}

This study employed the longitudinal research design. BRICS countries are selected for the study. Data for the study were generated from World Bank indicators (various issues), particularly from 1994:q1 to 2015:q4, the period of study. The study employs inferential statistics for the purpose of data analysis. While the inferential statistics however include the dynamic panel estimation generalized least square multivariate method, encompassing panel fixed/random effect.

Model Specification: The model is

$$
\text { RGDPGR }=\text { F(MCAP, TVSTR, TR AND INFR) }
$$

Restated in stochastic form

$$
\text { RGDPGR }_{\text {it }}=\beta_{0}+\beta_{1} \text { MCAP }_{\text {it }}+\beta_{2} \mathrm{TR}_{\mathrm{it}}+\beta_{3} \mathrm{TVSTR}_{\mathrm{it}}+\beta_{4} \mathrm{INFR}_{\mathrm{it}}+\mu_{\mathrm{it}}
$$

Where

$\beta_{1}$ to $\beta_{4}$ represents coefficient of the parameters of estimation

$\mathrm{i}$ represents individual countries of BRICS and $t$ is the period in question.

RGDPGR real GDP growth rate

MCAP represents market capitalization

TR represents turnover ratio

TVSTR represents total value of traded ratio

Inflation represents core inflation rate.

A priori expectations are $\beta_{1}$ to $\beta_{4}>0$.

\section{Empirical Analysis}

Table 1. Summary of unit root

\begin{tabular}{llll} 
Variables & ADF test at level & Critical statistic value at 5\% & Meaning \\
\hline RGDPGR & -3.409733 & -2.867066 & Stationary at level \\
\hline MKTCAP & -17.40610 & -2.867112 & Stationary at first difference \\
\hline TVSTR & -3.090406 & -2.867078 & Stationary at level \\
\hline TR & -4.678361 & -2.867089 & Stationary at level \\
\hline INFR & -5.826216 & -2.867066 & Stationary at level
\end{tabular}

Source: Computed from E-view 8.0

The unit root test of the time series for BRICS shows that some of the variables were stationary at levels while others were stationary at first difference. For example, the table above reveals that RGDPPGR, TR and INFR were stationary at level; while MKTCAP and TVSTR are stationary at first difference at 5\% level of significance. This explains that the existence of unit root among the variables cannot be accepted. 
Table 2. Diagnostic tests result

\begin{tabular}{lll}
\hline VARIABLES & Variables Inflation Factors (VIFs) & Centred VIF \\
\hline MKT CAP & Uncentered VIF & 1.38 \\
\hline TVSTR & 1.64 & 6.98 \\
\hline TR & 2.11 & 6.82 \\
\hline INFR & 21.79 & 1.29 \\
\hline F-statistic = 13.64 & 0.03 & \\
\hline Obs $*$ & Breusch - Godfrey - Serial correlation LM test & 0.0002 \\
15.06 & Prob. $(F 2,18)$ & Pro.Chi-square (2) 0,765 \\
\hline F-statistic 0.34 & Heteroskedasticity test Harvey & \\
\hline Obs $*$ R-squared 1.60 & Prob. Chi-square (4) & 0.84 \\
\hline Ramsey Reset Test & & 0.80 \\
\hline t-statistics = 2.38 & Df = 19 & \\
\hline f-statistic =5.67 & Prob. (F1, 19) & 0.02 \\
\hline
\end{tabular}

Source: Authors' computation

Table 2 shows that the variance inflation factor statistic is less than 10 (centered VIF < 10) for each of variables. This indicates absence of multicollinearity among the explanatory variables. The ARCH (Harvey) for heteroskedasticity test shows the presence of homoscedasticity $(0.84>0.05)$, thus confirming the constant variance assumption of the ordinary least square estimator. The Breusch-Godfrey serial correlation LM test result of $(0.765>0.05)$ points out the absence of higher correlation. The Ramsey Reset Test result of $(0.02>0.05)$ substantiate validity of the regression model.

Pooled Least Squares Fixed Effect Model Regression Equation

$$
\begin{aligned}
& \text { RGDPGR }=0.470 \mathrm{C}-0.030 \mathrm{MKTCAP}-0.111 \mathrm{TR}+0.368 \mathrm{TVSTR}-0.042 \mathrm{INFR} \\
& \begin{array}{lllll}
(7.911) & (-4.094) & (-10.181) & (16.203) & (-3.130)
\end{array}
\end{aligned}
$$

$\mathrm{t}-$ statistics are in parentheses with their probabilities below them.

R-squared $=0.1612$

Adjusted R-squared $=0.1596$

F-statistic $=100.66(0.000)$

Durbin Watson statistic $=1.55$

Cross country analysis of BRICS was quite robust judging with the F-statistic value of 100.66 of the pooled least square model. Overall, the model is significant at the parsimonious $1 \%$ level indicating that the regression jointly explained fluctuation in the regressand. All estimated coefficients were significant at $1 \%$ level and wrongly signed except TVSTR. Particularly MKTCAP and TR reduce GDP growth rate among the group (BRICS) while TVSTR and INFR promote unit increases in MKTCAP and TR will reduce real GDP growth rate by $0.03 \%$ and $0.11 \%$ respectively whereas unit increases in TVSTR and INFR will raise GDP growth rate by $0.36 \%$ and $0.04 \%$ respectively, this result shows that capital market activities were not adequate to boost growth rate of real GDP.

Presentation of Hausman test result: From this development, other estimating techniques may be considered for robustness and to ascertain the adequacy and influence of the capital market on growth rate of real GDP among member nations of BRICS. Hausman test need to be conducted to inform a choice of a more appropriate technique to adopt between the fixed or random effect model. The Hausman test is employed to test for the exogeneity of the 
unobserved error component (Igbinosa and Ogbeide, 2015). The test is necessary because the random effect needs to be uncorrelated with the explanatory variables; otherwise there is endogeneity problem and the random problem effect estimator will be inconsistent. The null hypothesis for the Hausman test is: $\mathrm{H}_{0} \beta_{\mathrm{RE}}=\beta_{\mathrm{FE}}$ Where $\beta_{\mathrm{RE}}$ and $\beta_{\mathrm{FE}}$ are coefficient vectors of the time-varying explanatory. Thus, if null hypothesis is rejected, the conclusion that can be drawn is that random effect (RE) model is inconsistent; and the fixed effects (EF) model will be preferred. Therefore, the Hausman test result of our model is presented below:

Table 3. Hausman test result

\begin{tabular}{lllll}
\hline Test Summary & Chi-square Statistic & Chi-Sq.d.f. & Prob. & \\
\hline Cross section random & 3206.93 & 4 & 0.0000 & \\
\hline Cross section random effects test comparisons & & & Prob. \\
\hline Variable & Fixed & Random & Var (Diff.) & 0.0000 \\
\hline MKTCAP & -0.229 & -0.030 & 0.0000 & 0.0000 \\
\hline TR & -0.341 & 0.368 & 0.0000 & 0.0000 \\
\hline TVSTR & 0.288 & 0.042 & 0.0002 & 0.0000 \\
\hline INFR & -0.092 & & 0.0000 & \\
\hline
\end{tabular}

Source: Computed from E-view 8.0

An observation of the conducted Hausman's test for this study suggests that the fixed effect model is preferable. This decision is based on the significance of the estimated very large chi-square statistic value of 3206935090 which is highly significant at $1 \%$ level implying a rejection of the null hypothesis in favour of the fixed effect model.

Fixed Effect Model Regression Equation

$$
\begin{aligned}
& \text { RGDPGR }=0.408 \mathrm{C}-0.009 \mathrm{MKTCAP}-0.080 \mathrm{TR}+0.311 \mathrm{TVSTR}+0.030 \mathrm{INFR} \\
& \begin{array}{llll}
(7.332) & (-1.300) & (-7.585) & (14.484) \quad(-2.418)
\end{array} \\
& \begin{array}{lllll}
(0.000) & (0.193) & (0.000) & (0.000) & (0.015)
\end{array}
\end{aligned}
$$

R-squared $=0.270$

Adjusted R-squared $=0.267$

F-statistic $=96.78$

Prob $($ F-statistic $)=0.000$

Durbin Watson statistic $=1.75$

BRA-C $=1.796$

RUS-C $=-0.283$

IND-C $=-0.245$

$\mathrm{CHI}-\mathrm{C}=-0.451$

$\mathrm{SAF}-\mathrm{C}=-0.816$

Result of the estimated fixed-effect is quite good and highly significant following the probability value (0.00) of the F-statistic which validates the overall importance of the model. The fixed cross-sectorial constant term, and TVSTR were highly significant at $1 \%$ level; INFR was significant at 5\%. Again, all estimated coefficient were wrongly signed except that of TVSTR. Average growth rate of real GDP growth rate among member countries of BRICS stood at approximately $41 \%$ per period. Brazil, Russia and India have positive growth rate of real GDP while China and South Africa have a negative growth rate on average over the period. Particularly, Brazil has the highest among the group while South Africa has the least. Brazil's growth rate of real GDP has above the group's average by $179 \%$ and India which is second, has an average of $24.5 \%$ less than group's average. Russia (third), China (fourth) and South Africa (fifth) all have average growth rate of real GDP below the group's average by $28.3 \%, 45 \%$ and $81.6 \%$ 
respectively, the negative sign shows that the countries with negative signs contributed less than the average of the group total performance.

Basically this is a reflection of the extent to which capital market operations influence the growth rate of economic activities in these countries. On average, a unit increases in MKTCAP and TR variables will hinder growth rate of real GDP in BRICS by $0.01 \%$ and $0.08 \%$ respectively. This is a clear indication that members of this group need to further develop their capital markets in order for them to adequately drive economic growth. On the other hand, TVSTR and INFR both have a positive influence on real GDP growth in BRICS on the average. Specifically, unit rises in TVSTR and INFR would raise growth of real GDP in BRICS by $0.31 \%$ and $0.03 \%$ respectively. INFR positive impact on growth of real GDP in BRICS may be attributed to investors-domestic and foreign confidence in the economies of the group. In all, we can deduce that the capital market operations in BRICS significantly impact on real GDP growth rate.

\section{Discussion of Findings}

The BRICS have had fair share from the global financial crises recently. Nonetheless, stock market activities have continued unabated but in different dimensions among the BRICS. The empirical estimation from the sub-section above shows that stock market development contributed to the real GDP growth rate of the BRICS. The turnover ratio of the BRICS negatively affected the economy. The finding is in tandem with the BRICS report (2014). For example, the report has it that the turnover ratio as indicator of the depth of the stock market deepened considerably over the years in the BRICS. The indicator grew from a base of $115.9 \%$ in China to $229.6 \%$, almost in the past two decades; Brazil and South Africa have also witnessed a significant increase in the ratio from 2009 upward. Except during the global financial crises the stock market did well. This could be attributed to the integration of the BRICS financial market with world financial markets where there was a combine external financing of stock market from bonds, equities and loans. These have resulted to growth in investment, thus causing growth in the GDP of BRICS. The study further supports the prediction of O'Neil and Stupnytska (2009) concerning the growth of the BRICS group.

The market capitalization of the BRICS was observed to significantly improve the real GDP growth rate. The finding could be adduced to influx of direct and portfolio investment, China's share of the global market capitalization has grown astronomically, to the extent that it is being predicted that it is likely to overtake the US in terms of stock market capitalization by 2030. Overall, it can be summarized that stock market development impact significantly on the economic growth of the BRICS.

\section{Conclusion and Recommendations}

This study examined the relationship between the stock market development and economic growth of the BRICS. The study ascertained that stock market development exerts significant impact on economic growth of BRICS. Overall, the general empirical findings are in tandem with the theoretical framework that underpinned this study.

From the empirical findings, the study recommends that to engender the attainment of the GDP growth rate desired by the member countries of the BRICS, there has to be policies implementations that will enhance the supply of securities investment. This will stimulate trade in stocks and increase the stock market development. To enhance the growth and development of the emerging markets, the markets must encourage the development of more specialized securities such as derivatives and securitized debts, and mutual funds. These funds will enable the market to generate more capital, improve its depth and liquidity. South Africa inclusivity into the BRICS GDP club is not contributing much. Policies in South Africa should be geared towards stimulating its comparative contribution by rapidly growing its economy. Moreover, the weaknesses of each of the BRICS member country should be taken as policy focus and strategies necessary to strengthen them should be swiftly applied. If these suggestions are considered by the governments of these emerging nations, the chances are that the stock market will be highly stimulated; leads to economic enhancement and ultimately lead to the attainment of the prediction that the BRICS will overtake the G - 7 economies by 2027.

\section{References}

Acharya, D., Amanulla, S., \& Joy, S. (2009). Financial development and economic growth in Indian states; An examination. International Research Journal of Finance \& Economics, 24, 117-130.

Agrawalla, R. K., \& Tuteja, S. K. (2007). Causality between stock market development and economic growth: A case study of India. Journal of Management Research, 7, 158-168.

Ahn, J., \& Cogman, D. (2007). A Quiet revolution in China's capital markets. McKinsey Quarterly, 24, 18-24. 
Andrezo, A. F., \& Lima, I. S. (2002). Mercado Finance Eiro: Aspectosinstoricos Econceituais (2nd ed.). Sao Paulo: Thompson learning.

Bayar, Y., Kaya, A., \& Yıldırım, M. (2014). Effects of Stock Market Development on Economic Growth: Evidence from Turkey. International Journal of Financial Research, 5(1). https://doi.org/10.5430/ijfr.v5n1p93

Biswal, M. M., \& Veerashekhanappa, R. (2002). Understanding the growth in emerging stock Markets. Journal of Emerging Market Finance, 4, 227-261.

Biswal, P. C., \& Kamaiah, B. (2000). On Stock Market Development, Banks and Economic Growth in India. ISEC Working Paper No.69, Institute for Social and Economic Change, Bangalore.

Brasoveanu, L., Dragota, V., Catarama, D., \& Semenescu, A. (2008). Correlations Between capital market and development and economic growth: the case of Romania. Journal of Applied Quantitative Methods, 3(1), 64-67.

Brown, E. D., \& Nyeche, E. W. (2016). The Imperative of Stock Market on Economic Growth in Nigeria: The Endogenous Growth Model. Bus Eco Journal, 7, 200.

Chipaumire, G., \& Ngirande, H. C. (2014). How stock market liquidity impact economic growth in South Africa. Journal of Economics, 5(2), 175-192. https://doi.org/10.1080/09765239.2014.11884995

Clemente, A., Taffarel, M., \& Esepejo, A. E. (2013). The Brazilian stock market - dimension, structure, and main features. Retrieved from www.intechapen.com

Dailami, C., \& Atkin, G. (1990). Stock markets in developing countries: Key issues and a research Agenda, policy research and external affairs. Working Papers. The World Bank.

Deb, S. G., \& Mukherjee, J. (2008). Does stock markets development cause economic growth? A time series analysis for Indian economy. International Journal of Finance and Economics, 21, 142-149.

Duan, W. (2012). Informational cascades and software adoption on the Internet: An empirical investigation. MIS Quart, 33(1), 23-48. https://doi.org/10.2307/20650277

El-wassal, A. K. (2005). Understanding the growth in emerging stock markets. Journal of Emerging Market Finance, 4(3), 227-261. https://doi.org/10.1177/097265270500400302

Garcia, F.V., \& Liu, L. (1999). Macroeconomics determinants of stock market development. Journal of Applied Economics, 2(1), 29-59.

Global Sherpa. (2009). Retrieved from http://www.globalsherpa.org/bric-countries-brics

Ikikii, S. M., \& Nzomoi, J. N. (2013). An analysis of the effects of stock market development on economic growth in Kenya. International Journal of Economics and Finance, 5(11), 145-151. https://doi.org/10.5539/ijef.v5n11p145

Kamat, M. S., \& Kamat, M. (2007). Does financial growth lead economic performance in India? causality cointegration using unrestricted vector error correction models. MPRA Paper No. 6154-26. https://doi.org/10.2139/ssrn.1069481

Masoud, N. (2013). Stock Markets: A Catalyst for Economic Growth - Jan. Retrieved December 11, 2018, from https://www.researchgate.net/publication/291346260

Matos, O. C. (2003). Inter relacoes entre desenroluimento. Financeiro, export acoes, e. Cresamentoeconomico: Analyse da experience brasilera. Notas tech leas do Bancocental to Brazil, No. 4, Brasilia.

Moura, A. P. (2005). Importancia de um requires especial de tributancopana o mercado de capitals. In E. L. Bacha, \& F. Oliveira (Eds.), Mercados de capitais e creseimentoeconomicolicosinternalionais, desetosbrasileiros, Ro de Janeiro/sao Paulo: contra, Capa Livrarial ANBID.

MuQuing, M., Robert, A., \& Chang, L. (2001). An empirical study on the relationship Between stock market index and National Economy: The case of China. International Journal of Finance, 4(1), 13-31.

Najeb, M. H., \& Masoud, N. (2013). The Impact of Stock Market Performance upon Economic Growth. International Journal of Economics and Financial Issues, 3(4), 788-798. Retrieved from www.econjournals.com

Ndako, U. B. (2008). Financial development, Economic growth and stock market volatility: Evidence from Nigeria and South Africa, Nigerian experience. Australian Journal of Business and Management Research, 2(2), 20-30. 
Ngashi, M. (1999). Stock market development and economic growth: Dubious relationship. Economic and Political Weekly, 34(29), 2004-2012.

O’Neil, J. (2001). Building better global economic BRICS. Goldman Sachs Global Economic Paper, 66.

Olfa, C. (2007). Overreaction effect in the Tunisian stock market. Journal of Asian Business Strategy, 8(2), 134-140.

Osamwonyi, I. O., \& Kasimu, A. (2013). Stock market and economic growth in Ghana, Kenya and Nigeria. International Journal of Financial Research, 4(2), 83-98. https://doi.org/10.5430/ijfr.v4n2p83

Pan, L., \& Mishra, V. (2018, January). Stock market development and economic growth: Empirical evidence from China. Economic Modelling, 68, 661-673. https://doi.org/10.1016/j.econmod.2017.07.005

Ruyong, T. (1999). An empirical research on the relationship between China's financial development and economic growth. Economic Research Journal, 10(2), 18-37.

Sinha, D., \& Macric, J. (2001). Financial development and economic growth. The case of Eight Asian countries. Economic - Internazionale, 54(2), 219-234.

Sudharshan, R. P., \& Rakesh, G. (2011). An empirical analysis of stock market performance and economic growth: Evidence from India. International Research Journal of Finance and Economics, 7(3), 1-15.

Vazadikis, A., \& Adamopoulos, A. (2009). Stock market development and economic growth. American Journal of Applied Sciences, 6(11), 1993-1941.

Wang, B., \& Ajit, D. (2013). Stock market and economic growth in China. University of Northern British Columbia, Prince George, British Columbia, Canada.

Wang, E. (2002). The theoretical analyses on the relationship between China's capital market and economic growth. China Economist, 2, 1-10.

Wang, S. S., \& Li, W. (2004). Information diffusion, transaction costs, and the performance of technical trading rules in the emerging stock market in China. EFMA 2004 Basle Meetings Paper. https://doi.org/10.2139/ssrn.487783

Zhao, C. S. (2002). Corporate governance, stock market and economic growth in Brazil. Corporate Ownership \& Control, 6(2), 222-237.

Zheng, J., Yuan, G., \& Hu, Z. (2000). An empirical study on the connection between China's stock market and economic growth during the transforming period. Management World, 6, 15-24. 